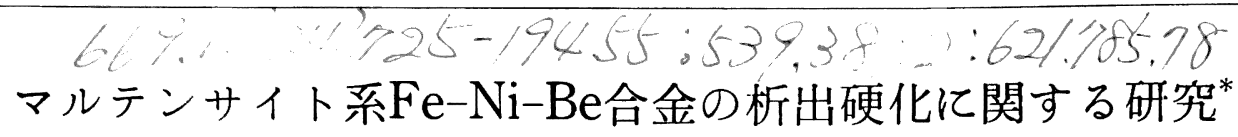

\author{
金尾正雄 ${ }^{* *} \cdot$ 荒木 透*** 沼田英夫** . 中野惠司 ${ }^{* *}$
}

\title{
Study on Precipitation Hardening of Martensitic Fe-Ni-Be Alloys
}

\author{
Masao Kanao, Toru Araki, Hideo Numata and Keishi Nakano
}

\begin{abstract}
Synopsis:
Age hardening behaviours and precipitation process of martensitic $\mathrm{Fe}-5 \% \mathrm{Ni}-\mathrm{Be}$ alloys were investigated. The results obtained were as follows:

(1) $\mathrm{Fe}-5 \% \mathrm{Ni}-\mathrm{Be}$ alloys containing $0.47 \% \mathrm{Be}$ or above were remarkably hardened by aging in the temperature range between $400^{\circ} \mathrm{C}$ and $550^{\circ} \mathrm{C}$ after water-quenched from austenite region.

(2) There were two types of equilibrium precipitates in the aged alloy. One was finely distributed general-type precipitate, and the other was stringer-like one produced by grain boundary reaction.

Both of them were $\mathrm{CsCl}$ type NiBe having lattice parameter of about $2 \cdot 62 \AA$. The reaction was suppressed by the addition of small amount of $\mathrm{Ti}$ or $\mathrm{Zr}$, accompaniedby significant improvement of hardening.

(3) Through the transmission electron microscopy and $\mathrm{X}$-ray diffraction analysis, it is considered that the alloys are hardened by the formation of clusters with ordered structure rich in solute arom on the matrix lattice.

(4) General-type precipitates were formed with the same orientation as the bcc martensite matrix. However, as the misfit of the two bcc lattices was relatively large, the coherency strain and in the lattice was possibly lost and the specimen was over-aged by the precipitation. Double diffraction phenomenon was often observed on the diffraction patterns from the precipitated specimens.

(5) $\mathrm{Fe}-5 \% \mathrm{Ni}-\mathrm{Be}$ alloys showed reversion phenomenon when they were re-heated for short period at e. g. $625^{\circ} \mathrm{C}$ after pre-aged for $7 \mathrm{hr}$ at $450-\mathrm{C}$.
\end{abstract}

(Received July 17, 1968)

\section{1. 緒言}

フェライトまたはマルテンサイト組織を有する $\mathrm{Fe}$ $\mathrm{Ni}-\mathrm{Be}$ 采合金が時効硬化することは, 以前から知られて いる1)2．実用鋼としてもかなり古くから用いられてお り3)，現在もおもにマルエージ鋼として開発が行なわれ ている4)ー7. 強化機構に関して, MorT ${ }^{3)}$ はベリリウムス テンレス钿V $2 \mathrm{~B}$ 析出硬化は主としてフェライトにお ける高温上低温でのベリリウム化物の固溶限の差による と述べている. FLOREEN22) は Fe-18Ni-0.44Be 台金を $1500^{\circ} \mathrm{F} \times 1 \mathrm{hr}$ 溶体化処理したのち，900 $\mathrm{F} \times 72 \mathrm{hr}$ 過時 効した試料の抽出レプリカを電子回折した。その結果析 出物のはつきりした回折像を得たが，既知の相と一致し ない結果在得ている。このように詳細な硬化機構注今日 においても泣とえどわかつていない。

そこで著者らは基本となる単純 $\mathrm{Fe}-5 \% \mathrm{Ni}-\mathrm{Be}$ 合金を 用い，その時効硬化機構について $2 ， 3$ 検討を行なつた ので報告する.

\section{2. 供試材および実験方法}

\section{$2 \cdot 1$ 供試材}

再電解鉄, 電解 $\mathrm{Ni}$ 抢よび約 $6 \%$ の $\mathrm{Be}$ を含む $\mathrm{Fe}-\mathrm{Be}$
母金金用いて，真空高周波誘導炉で約 $3.5 \mathrm{~kg} の \mathrm{Fe}-$ $50 \% \mathrm{Ni}-\mathrm{Be}$ 合金を数種溶製した. $1200^{\circ} \mathrm{C}$ に加熱して 10 $\mathrm{mm} \phi$ 丸棒に压延し供試材とした. Table 1 に供試材の 化学成分を示した．このうち試料 No 1 〜 3 は Be の量 を変えたものであつて，原子数でいえば $\mathrm{Be}$ は $\mathrm{Ni}$ の大 体 1/5，3/5，1/1 を狙つたものである. また試料 No $4 ， 5$ 注粒界反応を抑える目的で $\mathrm{Fe}-5 \% \mathrm{Ni}-0.4 \% \mathrm{Be}$ 合 金に $\mathrm{Zr}$ または Ti を微量添加したものである。なお溶 体化処理としては $950^{\circ} \mathrm{C} \times 1 \mathrm{hr}$ 加熱後水冷処理を行な つた.

\section{$2 \cdot 2$ 実験方法}

おもにビッカース硬さ測定によつて時効の効果を調べ マルテンサイトマトリクスの格子定数測定, 電解残査の X線回折，レプリカおよび薄膜試料の電顕観察および電 子回折などによつて硬化機構を調べた、マトリクスの格 子定数の測定は, $\mathrm{X}$ 線ディフラクトメーターで, フィル タ一を通さない $\mathrm{Fe} \mathrm{X}$ 線を使用して行なつた．背面反射 範囲に生じた (211) $K_{\beta}$ と $K_{\alpha},(200) K_{\beta}$ と $K_{\alpha}$ および

* 昭和 42 年 10 月, 43 年 4 月本会講演大会にて発表 昭和 43 年 7 月 17 日受付

** 金属材料技術研究所

*** 東京大学工学部工博 
Table 1. Chemical composition of alloys tested. (wt \%)

\begin{tabular}{|c|c|c|c|c|c|c|c|c|c|c|c|}
\hline Alloy No & C & $\mathrm{Ni}$ & $\mathrm{Be}$ & $\mathrm{Mn}$ & $\mathrm{Si}$ & $\mathrm{Cu}$ & $\mathrm{P}$ & $\mathrm{S}$ & $\mathrm{Zr}$ & $\mathrm{Ti}$ & $\Sigma \mathrm{N}$ \\
\hline 1 & 0.036 & $5 \cdot 03$ & $0 \cdot 15$ & $<0.001$ & $0 \cdot 003$ & $<0.001$ & 0.001 & $0 \cdot 003$ & & & 0.0014 \\
\hline 2 & $0 \cdot 003$ & $4 \cdot 83$ & 0.47 & $<0.001$ & 0.003 & $<0.001$ & $0 \cdot 001$ & 0.004 & & & 0.0014 \\
\hline 3 & 0.006 & $5 \cdot 06$ & $0 \cdot 81$ & $<0.001$ & $0 \cdot 003$ & $<0.001$ & $0 \cdot 002$ & 0.004 & & & 0.0010 \\
\hline 4 & 0.003 & $5 \cdot 04$ & $0 \cdot 38$ & & & & 0.001 & $0 \cdot 004$ & 0.004 & & $0 \cdot 0043$ \\
\hline 5 & 0.003 & $4 \cdot 95$ & $0 \cdot 38$ & & & & 0.001 & 0.004 & & $0 \cdot 10$ & 0.0016 \\
\hline
\end{tabular}

(310) $K_{3}$ の5本の回折線からそれぞれ格子定数を算蚛 し, $\sin ^{2} \theta$ こ対してプロットして, $\theta=90^{\circ}$ に直線的に外 挿して 5 桁まで求めた。本実験におけるマトリクスは $\mathrm{Ni}$ マルテンサイトで立方晶であり，格子定数の測定は 比較的容易であつた。

析出物同定のための残査の抽出は，5〜10\%の燐酸水 溶液中二, $10 \mathrm{~mA} / \mathrm{cm}^{2}$ の電流密度で電解抽出した。 残

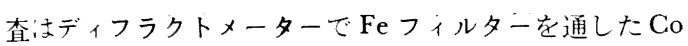
X缐志用い一回折した：

電䫒直接観察の薄膜試料は，熱処理した $10 \mathrm{~mm} \phi$ 棒り試籵より，圧延方向に直角に約 $0.7 \mathrm{~mm}$ の薄片を機 械的に切り出し, エメリ一紙研摩と化学研摩（弗酸 $5 \%$ 過酸化水素水 $85 \%$, 水 $10 \%$ ) で約 $50 \mu$ に予備研摩した のち, 水酷酸 $135 \mathrm{cc}$, 無水ク口ム酸 $25 \mathrm{~g}$, 水 $7 \mathrm{cc}$ の電 解液妾用い, Bollmann法で電解研摩した。

\section{3. 実鈤結果と考察}

\section{$3 \cdot 1$ 熱処理の影響}

Fig. 1 :二試料 No 1 3 を溶体化処理後 $300 \sim 700$ C の温度に各 $5 \mathrm{hr}$ 時効した試料のビッカース硬さ $(\mathrm{Hv})$ を 示した：試料 No1 の焼入机硬さはNo 2 より高いが こ行济 Table 1 でわかるようにC 量が多いのが主原因 てあろう. Be 0.15\%の試料 No 1 は時効硬 化汉られず，時効温度 $400^{\circ} \mathrm{C}$ 付近から焼も どしによる軟化が始まつている，Be 0.47\% を 含先試料 No 2 は； $5 \mathrm{hr}$ 時効では $500^{\circ} \mathrm{C}$ で最 大の硬化を示しており，さらに Be の多い試料 No 3 : 450がピークであつた.

Fig. 2 : 恒温の時効硬化曲線である. $450^{\circ} \mathrm{C}$ 時効では, 試料 Nol に㵊初焼もどし効果 による軟化がわずかにみられたが，長時間時効 する之わずかに硬化した，Be 量が多くなるに したがつて時効硬さのピークは短時間側に移行 し，なつ到達硬さも著しく高くなつて，試料 No 3 ては Hv 約 700 になつた. また試料 No 2 について時効温度の影響をみると，400 $\mathrm{C}$ て は $100 \mathrm{hr}$ 時効してもピークに達せず, 450 C と

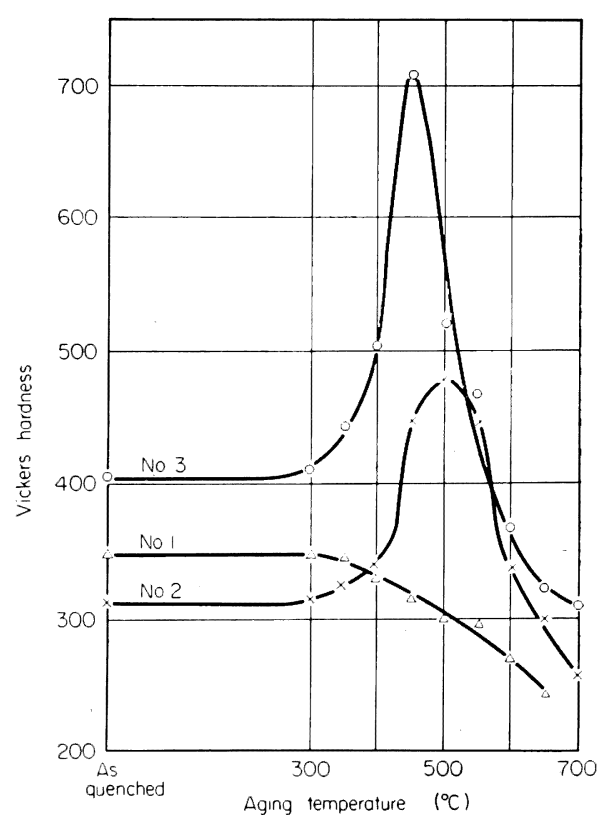

Fig. 1. Effect of aging temperature for $5 \mathrm{hr}$ on aged hardness of $\mathrm{Fe}-5 \% \mathrm{Ni}-\mathrm{Be}$ alloys water quenched from $950^{\circ} \mathrm{C}$.

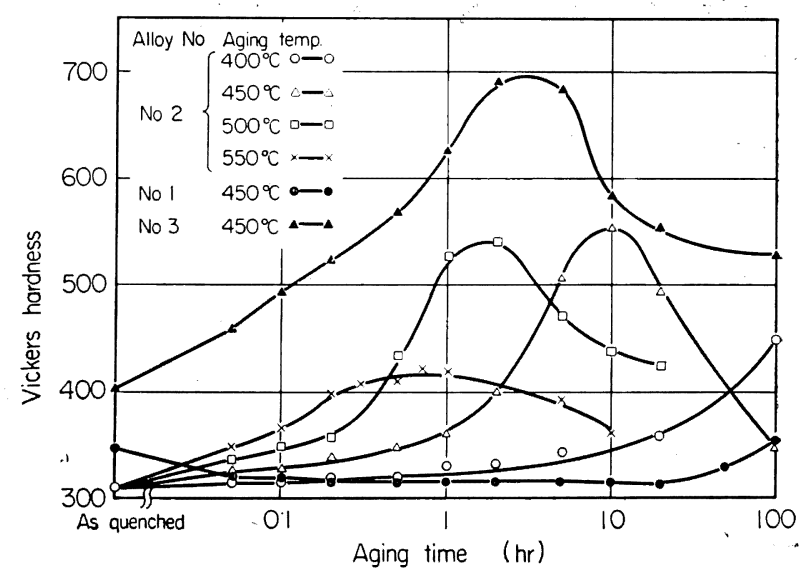

Fig. 2. Effect of aging temperature and Be content on age hardening curves of $\mathrm{Fe}-5 \% \mathrm{Ni}-\mathrm{Be}$ alloys. 
Table 2. Effect of various heat treatments on $\mathrm{Hv}$ of $\mathrm{Fe}-5 \% \mathrm{Ni}-0.5 \% \mathrm{Be}$ alloy.

\begin{tabular}{|c|c|c|c|c|}
\hline Alloy No & $950^{\circ} \mathrm{C} \times 1 \mathrm{hr}$ WQ & $\begin{array}{ll}950^{\circ} \mathrm{C} \times 1 \mathrm{hr} & W Q \\
450^{\circ} \mathrm{C} \times 5 \mathrm{hr} & W Q\end{array}$ & $\begin{array}{ll}950^{\circ} \mathrm{C} \times 1 \mathrm{hr} & \text { WQ } \\
700^{\circ} \mathrm{C} \times 5 \mathrm{hr} & \text { WQ }\end{array}$ & $\begin{array}{l}950^{\circ} \mathrm{C} \times 1 \mathrm{hr} \text { WQ } \\
700^{\circ} \mathrm{C} \times 5 \mathrm{hr} \mathrm{WQ} \\
450^{\circ} \mathrm{C} \times 5 \mathrm{hr} W Q\end{array}$ \\
\hline $\begin{array}{l}\text { No } 2 \\
\text { No } 3\end{array}$ & $\begin{array}{l}310 \\
402\end{array}$ & $\begin{array}{l}449 \\
707\end{array}$ & $\begin{array}{l}257 \\
312\end{array}$ & $\begin{array}{l}255 \\
315\end{array}$ \\
\hline
\end{tabular}

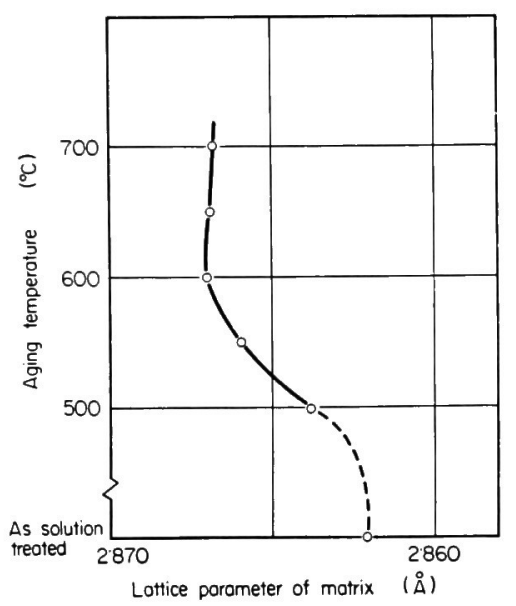

Fig. 3. Effect of $5 \mathrm{hr}$ aging on lattice parameter of quenched $\mathrm{Fe}-5 \% \mathrm{Ni}-0.5 \% \mathrm{Be}$ alloy.

$500^{\circ} \mathrm{C}$ 時効では $\mathrm{Hv}$ 約 240 の硬化により 540 前後に まで硬化し， $550^{\circ} \mathrm{C}$ 時効では過時効を示した，以上のよ うに一般にみられる時効特性を示した。

$\mathrm{Fe}-\mathrm{Ni}-\mathrm{Al}$ 合金においては, フェライト $(\alpha)$ に対する 析出相 $\mathrm{NiAl}$ の固溶限が, $600^{\circ} \mathrm{C}$ 付近からいちじるしく 変化して $700^{\circ} \mathrm{C}$ では非常に大きくなるため， $\alpha$ からオ ーステナイト $(\gamma)$ への変態が高温で生ずる低 $\mathrm{Ni}$ 含有量 の場合には, 約 $700^{\circ} \mathrm{C}$ 以上の $\alpha$ 領域で溶体化処理する と, $\boldsymbol{\gamma}$ 領域で溶体化処理した場合とほぼ等しい時効硬化 能が生ずる8). 同じ現象が $\mathrm{Fe}-\mathrm{Ni}-\mathrm{Be}$ 合金においても存 在するかどうか調べるため, $700^{\circ} \mathrm{C} の \alpha$ 相溶体化処理に 関する穾験を行なつた．結果を Table 2 に示した. そ の結果, $700^{\circ} \mathrm{C} \times 5 \mathrm{hr}$ の熱処理を行なつたものは, $450^{\circ} \mathrm{C}$ 時勃によつて全く硬化を示さなかつた。したがつて $\mathrm{Fe}-\mathrm{Ni}-\mathrm{Be}$ 三元合金では，Fe-Ni-Al 系と異なり $\alpha$ 領域 での溶体化処理実用の可能性は薄い，Fig. 3 はいろいる の温度で $5 \mathrm{hr}$ 時効したときのマトリクスの格子定数の 変化を示したものである. Be 原子が小さいため, $\mathrm{Be}$ に関する金属間化合物が析出すると, 格子定数は増大す る.この曲線の $600^{\circ} \mathrm{C}$ 以上の温度の部分は, この熱処 理条件での溶解度曲線ともいえる、 $\mathrm{Fe}-\mathrm{Ni}-\mathrm{Al}$ 合金の場 合と異なり, $\mathrm{Fe}-\mathrm{Ni}$-Be 合金では，ほとえど変化を示さ ず，上述の結果になつたものと考えられる.

\section{2 組析出相の同定}

Photo. 1 は試料 No 1 3 の溶体化処理状態の光学顕 微鏡組織である.角ばつた粒界をしており，マッシブマ ルテンサイトであることを示している． Be 含有量が増 加するとともに結晶粒が著しく微細化した. Photo. 2 a は試料 No 2 を $450^{\circ} \mathrm{C} \times 2 \mathrm{hr}$ 時勃した場合であるが, $450^{\circ} \mathrm{C}$ 時効て時効硬さのピークに達するまでは, 光学顕 微鏡にはつきりした変化は生じなかつた. Photo. 2 b は

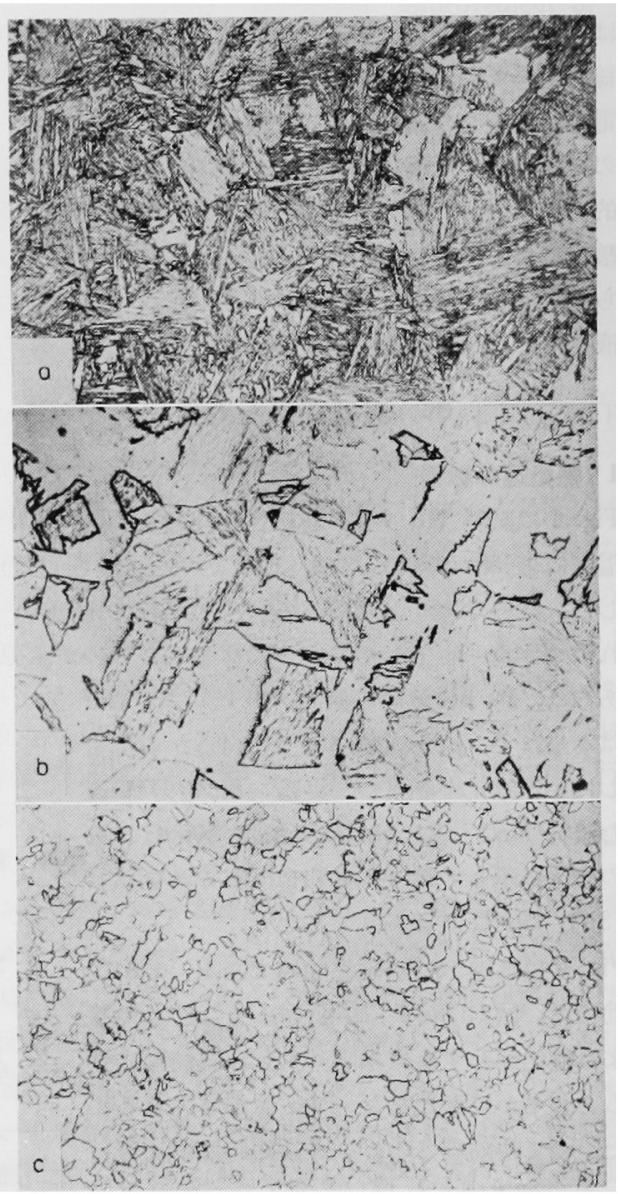

Photo. 1. Microstructures of $\mathrm{Fe}-5 \% \mathrm{Ni}-0.5 \% \mathrm{Be}$ alloy water quenched from $950^{\circ} \mathrm{C}$.

(a) Alloy No 1, (b) Alloy No 2, (c) Alloy No 3. $\times 240(2 / 3)$ 


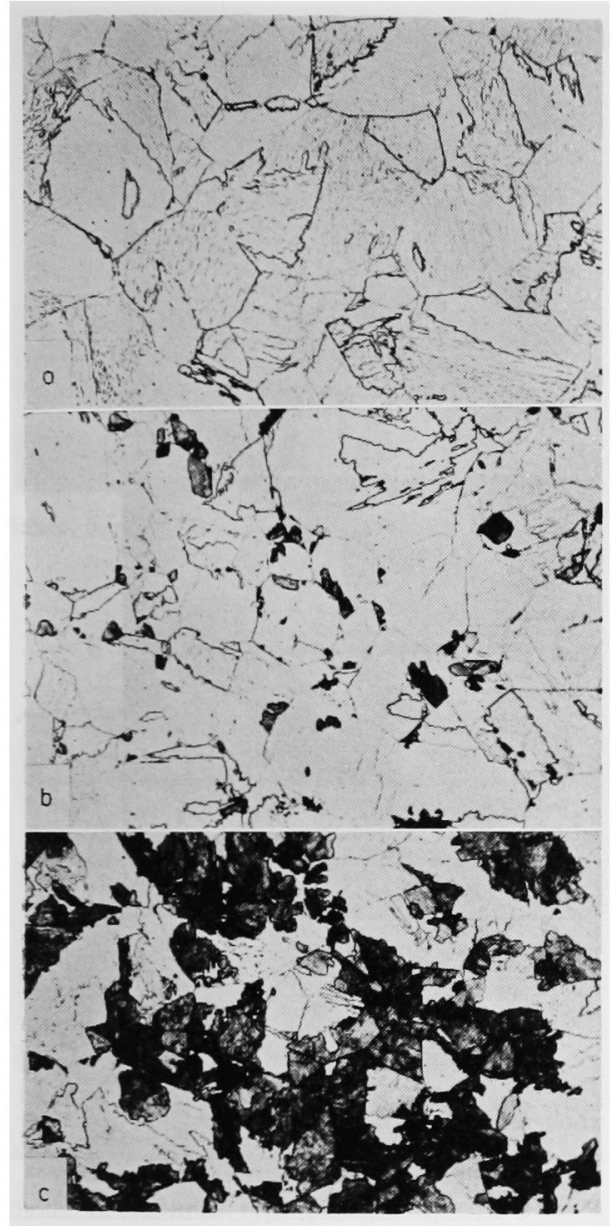

Photo. 2. Microstructures of $\mathrm{Fe}-5 \% \mathrm{Ni}-0.5 \% \mathrm{Be}$ alloy water quenched from $950^{\circ} \mathrm{C}$ and aged for (a) $2 \mathrm{hr}$ (b) $10 \mathrm{hr}$ (c) $20 \mathrm{hr}$ at $450^{\circ} \mathrm{C}$.

$\times 240(2 / 3)$

時効硬化のピークを示した $450^{\circ} \mathrm{C} \times 10 \mathrm{hr}$ 時効した試料 の光学顕微鏡組織であるが，黒く腐食された部分は粒界 反応が生じた部分である. 時効硬さのピークの直前から 粒界反応が生じ以後急速に発達することが観察された。

Photo. 3 は溶体化処理状態の試料の透過電顕写真であ るが，内部にタングルした転位を数多く含むラス (lath) から成り立つており，マッシブマルテンサイトである.

同じ $\mathrm{Ni}$ 量の場合 $\mathrm{Fe}-\mathrm{Ni}-\mathrm{Al}$ 合金ではマッシブフェライ トがかなり生じていた8ので，Be は焼入性をいちじるし く增加させるようである. ラスの境界注おもに約 $3,4^{\circ}$ 以内の小傾角境界であつた，このような組織において時 効が行なわれているので， $\mathrm{Ni}$ 量は比較的低いが，この 合金の時効はいわゆるマルエージということになる. Photo. 4 a は $450^{\circ} \mathrm{C} \times 8 \mathrm{hr}$ 時効した試料の組織である

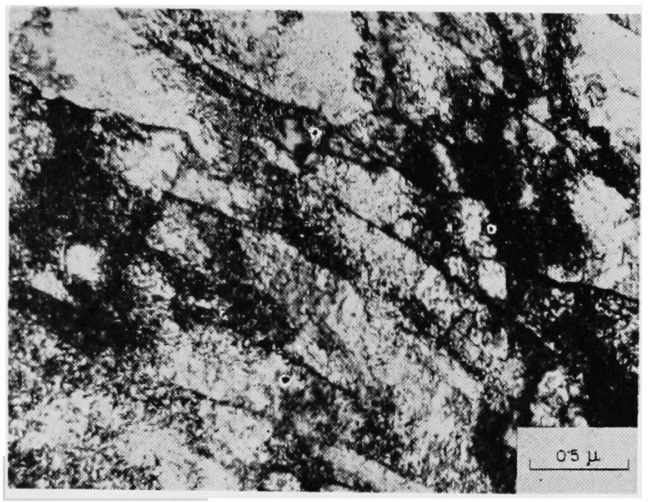

Photo. 3. Transmission electron micrograph of $\mathrm{Fe}-$ $5 \% \mathrm{Ni}-0.5 \% \mathrm{Be}$ alloy water quenched from $950^{\circ} \mathrm{C}$ showing massive martensite.

が, 溶体化処理状態の組織と比較すると, いくらか転位 の再配列が始まつているように見受けられる程度であ つて，その他の変化は確認することができなかつた。

Photo. 4 b : $450^{\circ} \mathrm{C} \times 20 \mathrm{hr}$ 時効したものであるが，夕 ングルした転位はかなりはつきりしてきて, 転位線上に 析出が始をつているようにみうけられる. Photo. 4 c は 同じ条件であるが，粒界反応が始まつている部分であ る. 過時効状態が進むと粒界反応による析出物以外に, 粒内にも析出物が観察されたが，その例をPhoto. $4 \mathrm{~d} に$ 示した。

析出相を同定するたかに, $550^{\circ} \mathrm{C} \times 7 \mathrm{hr}$ 洔効した試料 の電解残査をX線回折した. Table 3 にその結果を示し たが，NiBe によく一致した. NiBe は表中 * 印が示す ように規則格子であつて， NiAl と同じ CsCl 型 (B 2 構造）であり，体心立方格子の体偶を $\mathrm{Ni}$ が占め，体心 を Be が占めたものである. そして析出相とマトリクス の格子定数の差注約 $9 \%$ あ゙あつた。

著者らはこれまで $\mathrm{Fe}-5 \mathrm{Ni}-\mathrm{Al}$ 合金の析出挙動につい て研究 ${ }^{899} し, \mathrm{NiAl}$ がマトリクスにコヒレントに析出す ることを示した，そしてマトリクスと析出物がいずれも bcc 構造であり，かつ格子定数の差が $0.5 \%$ でごく小 さいという特徴があり, 通常の析出現象と著しく異なつ た挙動を示すのも，このことが大きな影響を与えている ものと考えられる. Fe-Ni-Be 合金においては, 結晶構 造については Fe-Ni-Al 合金の場合と全く同様であつた が，格子定数の差が大きいという特徵があり，この両采 の時効特性や硬化機構を比較することは興味深い.

すでに述べたように，この試料には粒界反応が生ずる ので，電解残査にはこの反応による大きな析出物と小さ い粒内析出物が混在するはずである. しかし上記X線回 


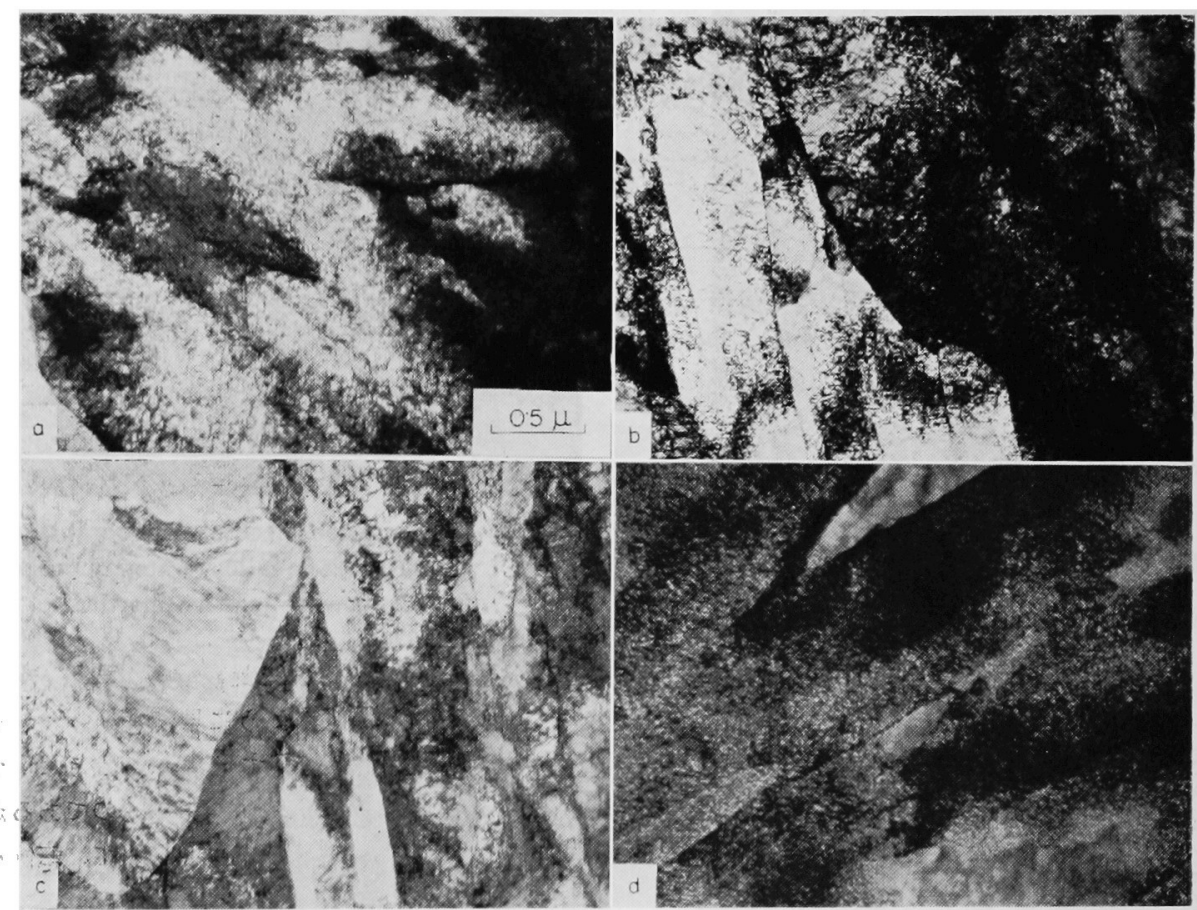

Photo. 4. Transmission electron micrographs of aged $\mathrm{Fe}-5 \% \mathrm{Ni}-0.5 \% \mathrm{Be}$ alloy.

(a) Aged $8 \mathrm{hr}$ at $450^{\circ} \mathrm{C}$, (b) Aged $20 \mathrm{hr}$ at $450^{\circ} \mathrm{C}$,

(c) Aged $20 \mathrm{hr}$ at $450^{\circ} \mathrm{C}$, (d) Aged $7 \mathrm{hr}$ at $550^{\circ} \mathrm{C}$,

Table 3. Results of $\mathrm{X}$-ray diffraction of electrochemically extracted residue.

\begin{tabular}{|c|c|c|c|c|c|c|}
\hline \multicolumn{3}{|c|}{ ASTM Card } & \multicolumn{4}{|c|}{ Alloy Number } \\
\hline \multicolumn{3}{|c|}{$\mathrm{Ni} \mathrm{Be}$} & \multicolumn{2}{|c|}{ No 2} & \multicolumn{2}{|c|}{ No 3} \\
\hline$d(\AA)$ & $\mathrm{I} / \mathrm{I}_{0}$ & $h k l$ & $d(\AA)$ & Intensity & $d(\AA)$ & Intensity \\
\hline $\begin{array}{l}2 \cdot 61 \\
1 \cdot 85 \\
1 \cdot 51 \\
1 \cdot 30 \\
1 \cdot 17 \\
1 \cdot 07 \\
0 \cdot 923 \\
0 \cdot 870 \\
0 \cdot 825\end{array}$ & $\begin{array}{r}80 \\
100 \\
60 \\
60 \\
70 \\
80 \\
60 \\
70 \\
80\end{array}$ & $\begin{array}{l}100^{*} \\
110 \\
111^{*} \\
200 \\
210^{*} \\
211 \\
220 \\
300^{*}, 221^{*} \\
310\end{array}$ & $\begin{array}{l}2 \cdot 623 \\
1 \cdot 852 \\
1.511 \\
1.308 \\
1 \cdot 170 \\
1 \cdot 056\end{array}$ & $\begin{array}{c}S \\
S \\
W \\
W W \\
W \\
M\end{array}$ & $\begin{array}{l}2 \cdot 623 \\
1 \cdot 852 \\
1 \cdot 512 \\
1 \cdot 306 \\
1 \cdot 171 \\
1 \cdot 068\end{array}$ & $\begin{array}{c}\text { S } \\
\text { S } \\
W \\
\text { VW } \\
\text { W } \\
\text { M }\end{array}$ \\
\hline \multicolumn{2}{|c|}{ Lattice parameter } & Precipitate matrix & \multicolumn{2}{|c|}{$\begin{array}{l}2 \cdot 6152 \AA \\
2 \cdot 8670 \AA\end{array}$} & \multicolumn{2}{|c|}{$\begin{array}{l}2 \cdot 6215 \AA \\
2 \cdot 8656 \AA\end{array}$} \\
\hline \multicolumn{2}{|c|}{$\left(d_{\text {matrix }}-d_{\mathrm{ppt}}\right) / d_{\text {matrix }}$} & $\times 100$ & \multicolumn{2}{|c|}{$8 \cdot 8 \%$} & \multicolumn{2}{|c|}{$8 \cdot 5 \%$} \\
\hline
\end{tabular}

* Superlattice reflection

折で 1 種類の相の回折図形しか存在しなかつた。これ は残查の中に細かい粒内析出物を抽出できなかつたか， 西るいは 2 種類の析出物の結晶形や格子它数に差がなか つたかのいずれかであろう、そこで抽出レプリカの電子
回折によつて 2 種颣の析出物を別々に同定した。

Photo. 5 : $550^{\circ} \mathrm{C} \times 7 \mathrm{hr}$ 時効した試料 No 2 の抽出 レプリカの電顕像であるが， 2 種類の析出物が存在してて いる. 回折像は粒内析出の部分の制限視野回折像である. 


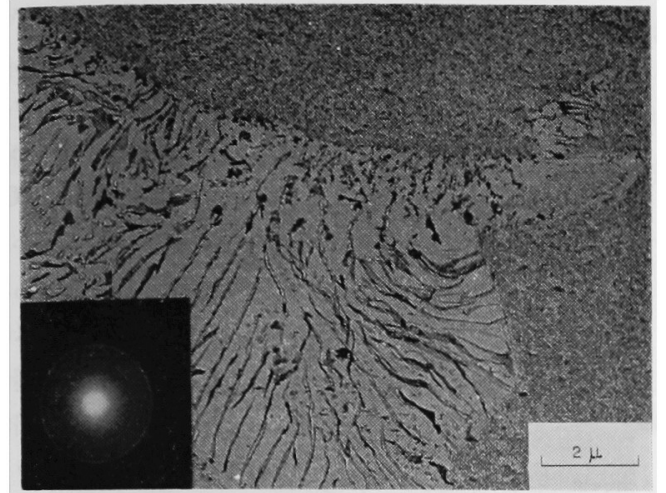

Photo. 5. General and cellular type precipitation of $\mathrm{Fe}-5^{\circ}, \mathrm{Ni}-0.5^{\circ}, \mathrm{Be}$ alloy water quenched from $950^{\circ} \mathrm{C}$ and aged $7 \mathrm{hr}$ at $550^{\circ} \mathrm{C}$ (extraction replica).

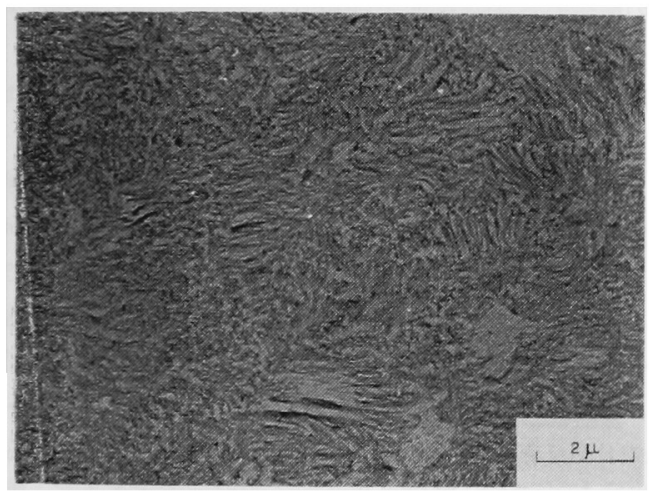

Photo. 6. Cellular type precipitation of $\mathrm{Fe}-5 \% \mathrm{Ni}-$ $0.5^{\circ}$. Be alloy water quenched from 950 $\mathrm{C}$ and aged $100 \mathrm{hr}$ at $450 \cdot \mathrm{C}$ (extraction replica).

ふ，規則格子反射も明りように認的ら机，CsGl 型の $\mathrm{Ni}$ Be てあつた。またこの粒界析出の部分方らも全く同様 な回折像が得られた。このように粒界反応を生ずること 安定析出相の結昆構造が粒界反応江上るもの上粒内析出 の両者とも同じであるこも，粒界反応析出物（七ル型新 出物）の形状力揫維状一あることなどは $\mathrm{Fe}-\mathrm{Ni}$ - $\mathrm{Al}$ 合 金 と同じであつた。ただ Ni3e のほうか粒琹反応型析出物 の層間隔の大きさの温度依存性が大光い。たと代 Photo. 6 は $450^{\circ} \mathrm{C} \times 100 \mathrm{hr}$ 時効した場合であるが, 550 ${ }^{\circ} \mathrm{C}$ と比較して層間隔の大ききが相当に買なつていた。

Fig. 4 は $\mathrm{Fe}-5 \mathrm{Ni}-0.4 \mathrm{Fe}$ 合金心対して, Zr 0.044\%を た注 Ti 0.1\%を添加した場合の影留を西したもので， 450 C の時効硬化曲線である. 標準の試料法 Hv 560 程 度に硬化するのに对して， $\mathrm{Zr}$ または $\mathrm{Ti}$ 微量添加す

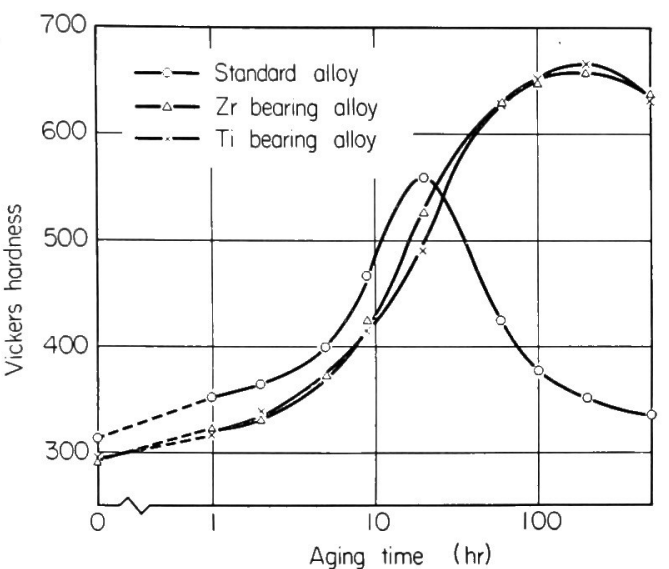

Fig. 4. Effect of alloying addition on hardness of $\mathrm{Fe}-5 \% \mathrm{Ni}-0.5 \% \mathrm{Be}$ alloy as a function of aging time at $450^{\circ} \mathrm{C}$.

ることによつて硬さは 670 汇洼した．光学顕微鏡で観 察すると， $\mathrm{Zr}$ また沈 $\mathrm{Ti}$ 添加合金には粒界反応が生じ ていないので，この上うな著しい硬化の相違を生ずるお も京原因は粒界反応が抑制されたことにあると考えられ 単純な Fe-Ni-Be 台金の強度に及ぼす粒界反応の影響注 いちじるしいものがある。

\section{3 析出過程について}

Fig. 5 は Zr 䘮微量添加して䊀界反応を抑制した試料 No 4 充 $500^{\circ} \mathrm{C}$ た㭙効したときの，時効時間による硬 さコマトリクスである立方晶のマルテンサイトの格子定 数の变化を示したものである.10hro時効で硬さはピー

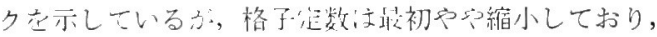
硬さのピークに達した付近から逆に增大に転じている： $\mathrm{Be}$ 原子: $\mathrm{Fe} \rightleftharpoons \mathrm{Ni}$ 原子と比䡆して小さいの一, Beを 含豆金属间化合物が析出寸ればマトリクスの恪子定数は 火きくなる法ずであう。したがつて，この合金の時効過 程は2段階にわか子，析出は硬化のピーク付近から始ま ると考えられる。そこで硬化の原因を調べるために，時 効初期状態に熱処理した試粼 No 2 上り薄膜試料字作 成し, 電子回折像の変化を中心唀渦電顕による観察を 行なつた。

Photo. 3 に示したように，時勃初期において流姑多い 蛙位がタングルして存在していることもあつて, 組織上 の恋化を電顕像しして確招することはできなかつたか， 回折像には变化が生じていた. Photo. 7 がその例であつ て，7 a は試料面か: (100) の場们であが，bcc 構造を

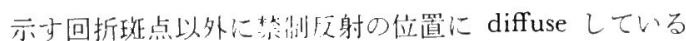
弱い回折玟点が現わ扎ている・声た 7 b は試料面が(110) の場公て西るが，やはり间情に diffuseした禁制反射斑 


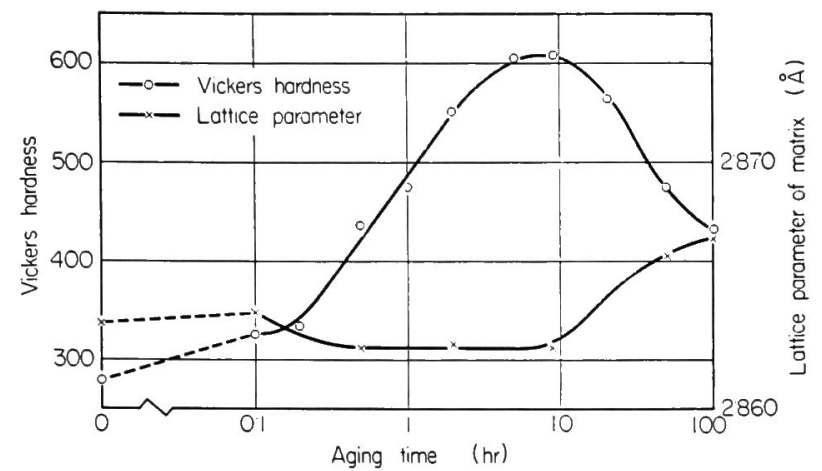

Fig. 5. Relationship between hardness and lattice pararreter of matrix of $\mathrm{Fe}-5 \% \mathrm{Ni}-0.4 \% \mathrm{Be}-0.04 \% \mathrm{Zr}$ alloy as a function of aging time at $500^{\circ} \mathrm{C}$.

点が現われ， a , b とも全体としてはあたかも単一の $\mathrm{CsCl}$ 型構造の回折像のように見受けられる.

すでに報告した $\mathrm{Ee}-\mathrm{Ni}-\mathrm{Al}$ 合金の場合を, 洔効すると やはり初期から単一の CsCl 型の回折像となり, その場 合は析出相の NiAl の格子定数がマトリクスとほぼ等し いので, 規則格子による回折斑点以外は, マトリクスと 析出相の斑点が重なつていると考えだ). しかし Fe$\mathrm{Ni}-\mathrm{Be}$ 合金の場合は析出相の格子定数は Feよりかなり 小さいので，たとえ同じ方位に析出したとしても分離し て見えるはずである。

電子回折像における禁制反射の出現から, 当然規則化 が生じている領域の存在が考えられる. そして得られた 回折像が単一の回折像を示したことから,この領域は母 格子上に形成されていると思われる.すなわち，母格子 上に $\mathrm{Be}$ や $\mathrm{Ni}$ に富む規則化された微細な集合体（クラ
スター）が多数形成されることによつて，いち じるしい硬さの増加が生ずるものと考えられ る.このようなコヒレントな規則化されたクラ スターは非鉄合金では，たとえば $\mathrm{Al}-\mathrm{Mg}-\mathrm{Zn}$ 合 金などに存在するといわれていて，規則化 G. P.ゾーンと呼ばれている10). 不規則状態から 規則化されると格子定数は隇少寸ると考えられ るので, 前述の時効初期におけるマトリクス格 子定数の減少は, このような母格子上の規則化 された領域の生成によるとも考えられる. 回折 斑点が diffuse していることから，このクラス ターの大きさはごく微細であろう・またこれま での実験の範囲内では特定の方向へのストリー クは認められなかつた。したがつて，この点か らクラスターの形状は球状ではないかと推定される. Be の原子直径が Fe とかなり相違しているので歪エネルギ 一が大きく，板状に形成されることも考えられるが，表 面エネルギーが大きいために球状になるのかもしれな v.

以上時効の初期の硬化段階について述べたが，つぎに 金属間化合物 NiBe の析出段階について調べた. Photo. $8 \mathrm{a}$ は $550^{\circ} \mathrm{C} \times 7 \mathrm{hr}$ 時効したときの透過電顕写真であ るが，無数の粒子が分散していて析出物と考えられる. そして bcc の禁制反射の位置に現われた回折斑点のビー ムを用いた暗視野像が: Photo. 8 b であるが，コントラ ストが反転しており，禁制反射が析出物からきているこ とがわかつた. Photo. 9 は別の視野の例であるが, 同様 な現象を示した、いずれの場合も回折像をみると数多く の回折斑点が生じており, 複雑であつた。

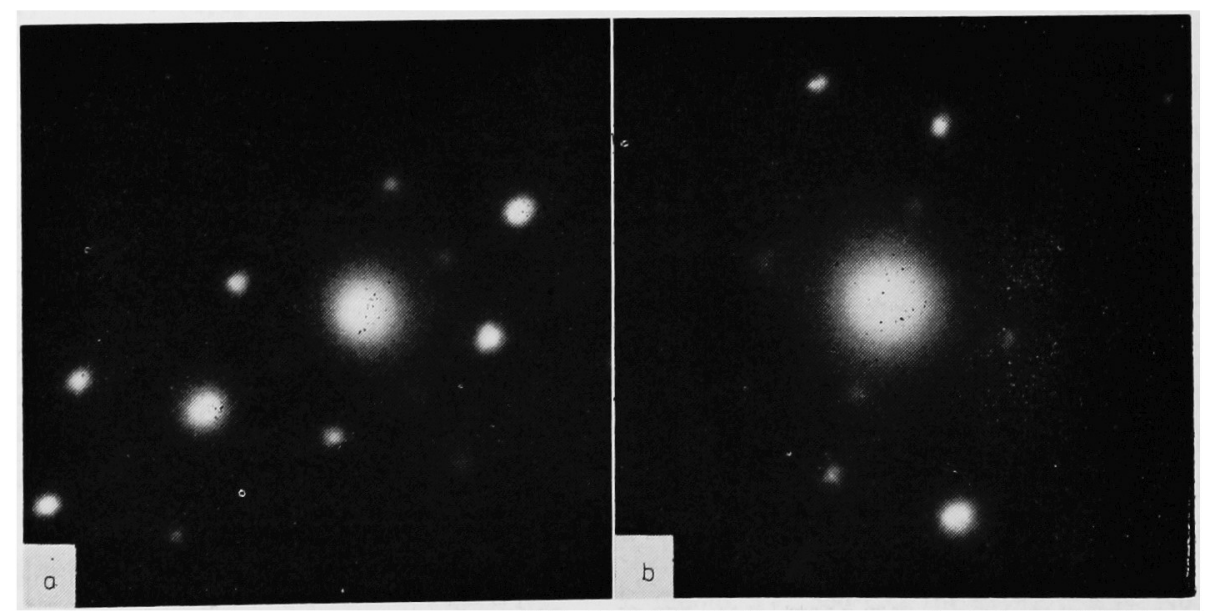

Photo. 7. Electron diffraction patterns of $\mathrm{Fe}-5 \% \mathrm{Ni}-0.5 \% \mathrm{Be}$ alloy quenched from $950^{\circ} \mathrm{C}$ and aged $7 \mathrm{hr}$ at $45 \mathrm{C}^{\circ} \mathrm{C}$. (a) (100) matrix $\perp$ bearr, (b) (110) matrix $\perp$ beam. 
Photo. 10 は過時効した試料から得られた電子回折像 の 2，3の例であるが，いずれにも多くの回折斑点が生 じていた. Photo. 10 a は立方晶マルテンサイトの (310) がビームに垂直な場合であるが，いずれの逆格子点も数

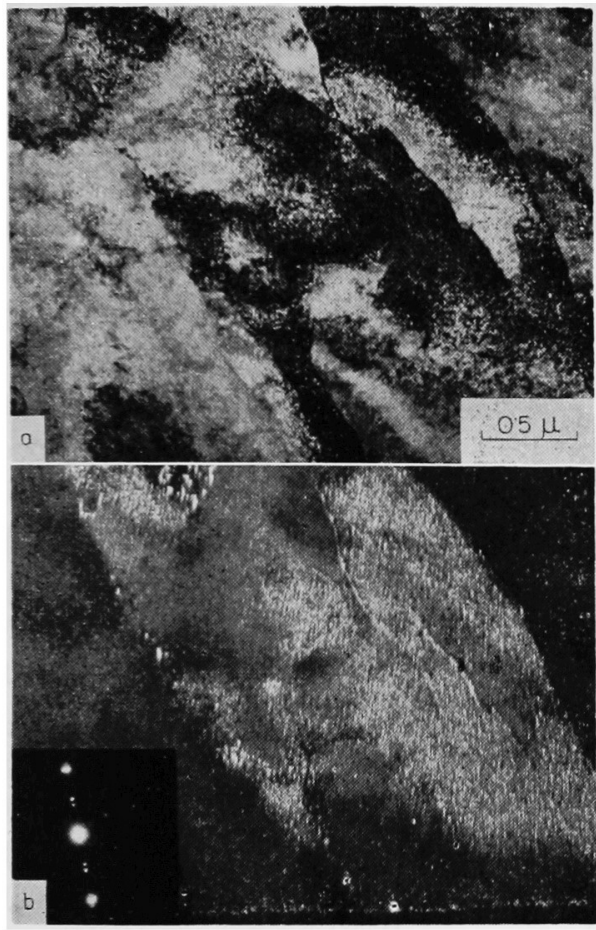

Photo. 8. Transmission electron micrographs of $\mathrm{Fe}-$ $5 \% \mathrm{Ni}-0.5 \% \mathrm{Be}$ alloy water quenched from $950^{\circ} \mathrm{C}$ and aged $7 \mathrm{hr}$ at $550^{\circ} \mathrm{C}$. (a) Brightfield, (b) Dark field micrograph from a super lattice reflection.

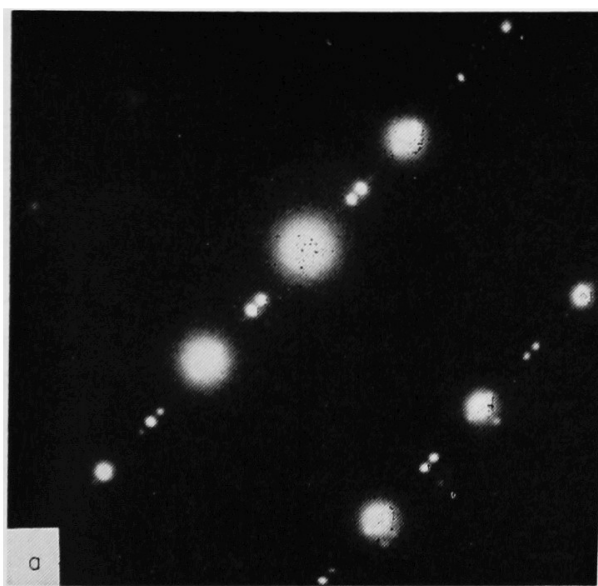

多くの回折斑点群からなつていて，多い場所では7〜8 筪存在していた. Photo. $10 \mathrm{~b}$ 娬料面が(100)の場合で ある

これらの数多くの回折斑点法，二重回折現象によつて

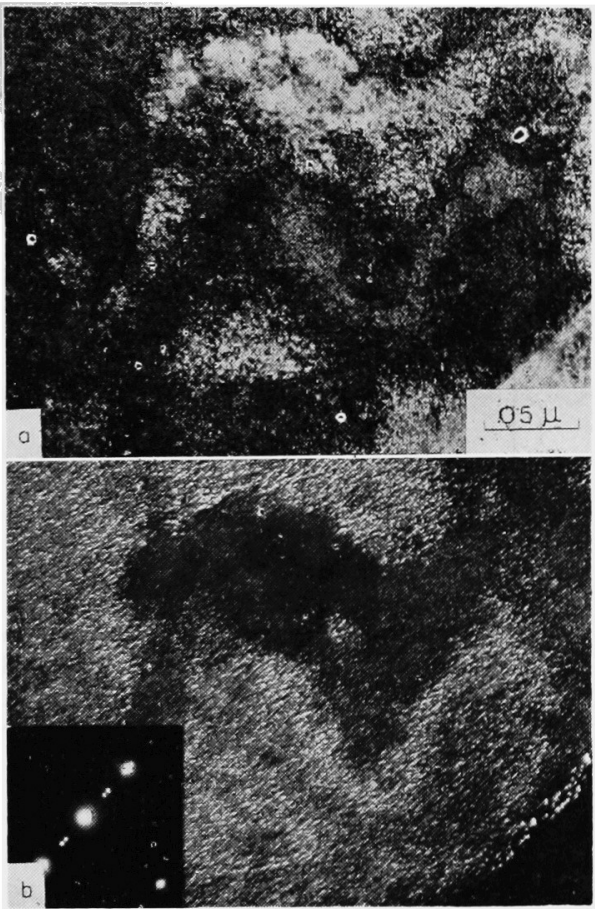

Photo. 9. Transmission electron micrographs of $\mathrm{Fe}-$ $5 \% \mathrm{Ni}-0.5 \% \mathrm{Be}$ alloy water quenched from $950^{\circ} \mathrm{C}$ and aged $7 \mathrm{hr}$ at $550^{\circ} \mathrm{C}$. (a) Brightfield, (b) Dark field micrograph from a super lattice reflection.

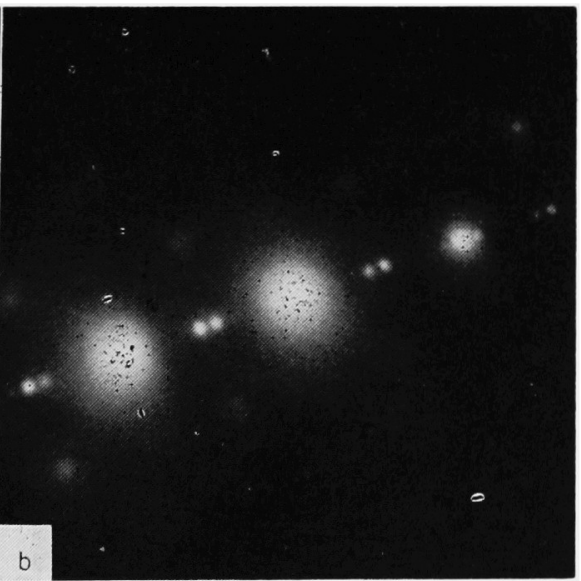

Photo. 10. Electron diffraction patterns of $\mathrm{Fe}-5 \% \mathrm{Ni}-0.5 \% \mathrm{Be}$ alloy quenched from $950^{\circ} \mathrm{C}$ and aged $7 \mathrm{hr}$ at $550^{\circ} \mathrm{C}$.

(a) (310) $\perp$ beam, (b) (100) $\perp$ beam. 
(a)

(c)
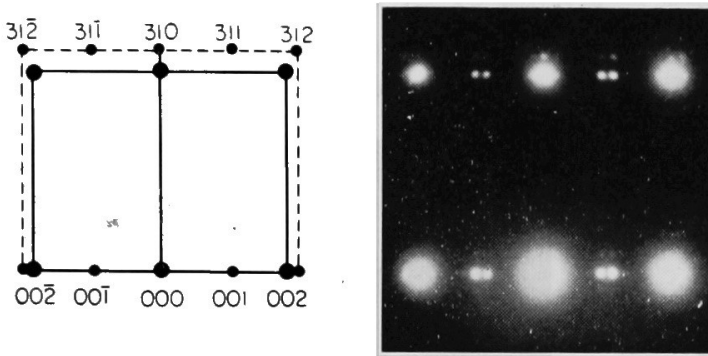

(b)

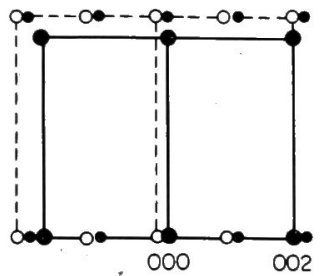

- Matrix reflections

- NiBe reflections

- Spots due to double diffraction

Fig. 6. The interpletation of the diffraction pattern obtained from aged $\mathrm{Fe}-5 \% \mathrm{Ni}-0.5 \%$ Be alloy. (a) Primary patterns, (b) The extra reflections due to double diffraction when the 200 beam of matrix acts as a secondary source, (c) Diffraction pattern of $\mathrm{Fe}-5 \%$ $\mathrm{Ni}-0.5 \%$ Be alloy aged $7 \mathrm{hr}$ at $550 \mathrm{C}$.

説明与ることができる。Fig. 6 流 Photo. 10 a の説明刹 である.（a）汶ルテンサイトの (310) がビームに垂直 な場合に, マルテンサイトレ同じ方位に NiBe が析出し たとき得られるであろう電子回折像を示したものであ

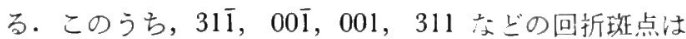
$\mathrm{NiBe}$ の規則格子反射七市る。、ルテンサィトの $(002)$ に よつて回折されたビームが，析出物に入つて再び回折き れたとすると，(002）の逆格子点が原点となりて，b图
の白丸の位置に回折斑点が新たに生ずるである う.このことが各母格子面の回折ビームについて 生ずると, 数多い回折斑点が現われるわけ下, c 図のーナくての余分な回折斑点は，これらが二重回 折によつて生じたよ考えた場合の位置に一致し た。

Photo. 11 a 泣重回折が生じていいな場合の 例である.マルテンサイトの (311) がビームに垂 直な場合であるか，いくつかの強いマトリクスの 回折斑点の近くに弱い回折斑点が存在している。 $11 \mathrm{~b}$ がその説明図であるが，弱い回折斑点はやは りbccの311 逆格子面を示しており, 格子定数か らいつて NiBe によるものである. 以上述べたい くつかの回折像から, 格子定数䄪 $2.6 \AA$ の $\mathrm{NiBe}$ がマトリクスと同じ方位をもつて析出していると 考えられる.

前に述べたように， $\mathrm{Fe}-5 \mathrm{Ni}-\mathrm{Be}$ 台金は時効によ つて母格子上に規則化クラスターが形成されるこ とによつて硬化するものと考えられる．ひきつゔ いて平衡析出の段階に入るが， $\mathrm{Fe}-5 \mathrm{Ni}-\mathrm{Al}$ 合金の 場合は析出物とマトリクスの格子定数の差がわず かであたい:，平衡析出段階においても整合性 をよく保ち, 時効開始から平衡析出が行なわれている間 連続的に硬化が進行し, さらに時効が進えでほとえど析 出が終わり, 凝集する段階に至つて軟化が省やかに生 ずるものと考えら机る。しかし Fe-5Ni-Be 合金ては, 格

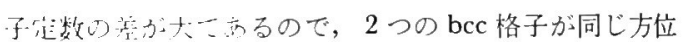
にあつても析出汇よつて整合性它失ない急速に軟化し始

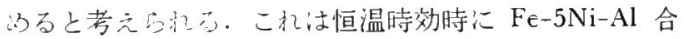
金ては時效硕化のピークに達する時間亡こにマトリクス a)

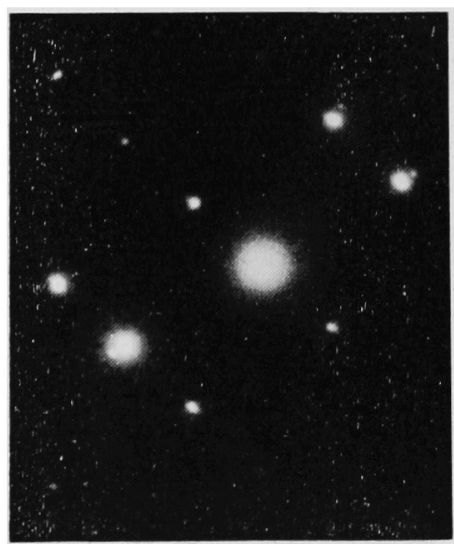

b)

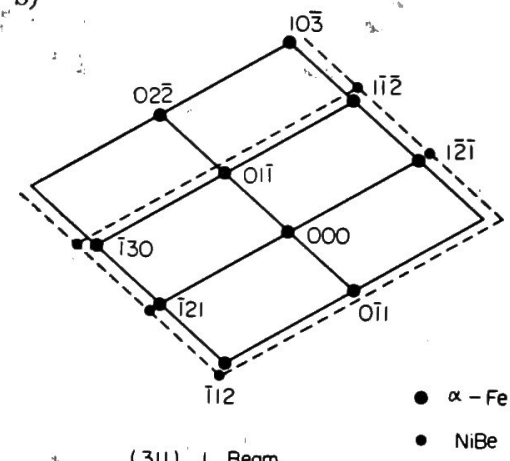

(3II)' $\perp$ Beam

1

Photo. 11. Electron diffraction pattern of $\mathrm{Fe}-5 \% \mathrm{Ni}-0 \cdot 5 \% \mathrm{Be}$ alloy quenched from $950^{\circ} \mathrm{C}$ and aged $7 \mathrm{hr}$ at $550^{\circ} \mathrm{C}$. 
の格子定数の変化が大部分終わるのに 対し, $\mathrm{Fe}-5 \mathrm{Ni}-\mathrm{Be}$ 合金では，時効硬化 のピーク付近から析出を意味する变化 が始まることと一政する。

\section{4 復 元}

Fig. 7 : $450 \cdot \mathrm{C} \times 7 \mathrm{hr}$ 時効して, Hv 532 になつた試料 No 2 を，62j C に短時間再加熱したょきの，硬さ とマトリクスの格子、数の变化を示し た。時矨した試料を短時間高温で再加 熱すると，いつたんすみやかに硬さが ほぼ時効前の值に戻り，ての後その温 度での時効硬化が生じた。この結果は この合金系に復元現象が存在与ること を示している・マトリクスの格子定数 は，前に述べたと同様に $450-\mathrm{C}$ 時効 でわずかに箖小し， $625^{\circ} \mathrm{C}$ 再加熱によ る軟化に対応して元に戻つており，て の後の時効硬化に対応して大きくなつ た.したがつてここの硬化注析出によ る硬化で市ろう. Fig. 8 注復元処理の 温度が $575 \mathrm{C}$ の場台でるが，前図 と比較すると復元ぶ不完全である。格 子定数の変化をみると, 高温時効に上 る軟化に対応して大きくなつて，時効 前に戻る傾向をみせた。てひ後 450 C 時効時と同じく硬化に対応する增大が みられ，これは溶体化処理㣪575 C で 直接時勃した場合上同じ傾向であつ た. Fig. 8 沪洝溶体化処理後，直接 575 C て時効した場合の硬化曲線をる 示したが，そのときの硬化量汢復元処 理して軟化したあ上の硬さの増加量よりもしろ少なかつ た。すなわち，復元処理したものには低温時効の効果が 残つているのて硬化量が大きく，もちろえ到達最高硬さ 法いちじるしい差が認蚂られた。 575 C 時効において は，復元した亦上の場合のほうが硬化汇寄与する溶質元 素の量がかなり少ない流ずであるにもかかわらず，硬化 量决添等しいので， $575 \mathrm{C}$ 時効における溶質元素に富 えたクラスターの分布状態や寸法など硬化を左右する因 子に, 前処理上しての低温時効の影響が生じていること が考えられる。

\section{4. 結}

\section{言}

$\mathrm{Fe}-5 \mathrm{Ni}-\mathrm{Be}$ 合金について，マルテンサイトマトリクス
におりる時効硬化特性を調べるとともに，硬化機搆につ い下娭討を行なつた。得られた結果を総括寸る上つきの とおりである。

(1) オーステナイト相 $(r)$ て溶体化処理した Fe50 oNi-Be 合金は，Be 量 $0.15 \%$ で活々えど洔効硬化 しなかつたか，0.47\% 交たはと机以上の場公400〜550

C の温度で著しく時効硬化した． $\gamma$ た溶体化処理して 水冷した組織は立方昆のマッシブマルテンサイトてあつ たのでこの時効はいわゆるマルエージである.

（2）この合金の時効には粒界反応が存在した。恒温 時効において，時効硬化のピークに達する直前の時効時 間から繊維状の析出物を含むセルが生じ，成長した。 セ ルの内部のマトリクスと析出物の層間隔の時効温度依存 
性は大きかつた：この粒界反応は $\mathrm{Ti}$ や $\mathrm{Zr}$ を微量添加 することによつて抑制することができ，その結果時効硬 さを著しく増加した。

(3) 平衡析出相は粒内析出物および粒界反応による 析出物のいずれも, 格子定数約 $2 \cdot 62 \AA$ で $\mathrm{CsCl}$ 型 (B 2 構造）の $\mathrm{NiBe}$ であり，マトリクスとの格子定数の差 は約 $9 \%$ あった。

（4）透過電子顕微鏡観察およびX線回折による格子 定数の測定などから, $\mathrm{Fe}-5 \mathrm{Ni}-\mathrm{Be}$ 合金は, 母格子上に $\mathrm{Be}$ や $\mathrm{Ni}$ に富む規則化されたクラスターが形成されること によつて硬化するものと考えられる.

(5) 平衡析出相の NiBe は立方晶のマルテンサイト と同じ方位に析出するが， $\mathrm{Fe}-\mathrm{Ni}-\mathrm{Al}$ 系と異なつて， 、 トリクスと析出物の格子定数の差が大であるため整合性 を早期に失なつて軟化した。なおその際マトリクスと析 出相法同じ体心立方であつて, 同じ方位に存在する上, 格子定数がくらか異なるためにしばしば二重回折現象 を生じた。

（6） $\mathrm{Fe}-5 \mathrm{Ni}-\mathrm{Pe}$ 合金には明りような復元現象が存在
した.

\section{交献}

1) H. B. Benneck und P. Schafmeister: Arch. Eisenhüttenw., 5 (1932) 12, S. 615

2 ) S. Floreen: Trans. Amer. Soc. Metals, 57 (1964), p. 38

3) N. F. Мотт: Iron Age, 171 (1953) June. 18, p. 149

$4)$ 田中, 谈原, 鈴木, 山本: 日本金属学会講演概要, (1964) 10 月, p. 89

5) J. Smolinski: J. Iron Steel Inst., 204 (1966), p. 57

6) 荒木, 佐川, 增井: 鉄と鋼, 53 (1967) 7, p.890

7 ) 日下, 岩丸, 荒木: 鉄と鋼, 53 (1967) 4, p.528

8 ）金尾, 荒木, 沼田, 青木: 鉄と鋼, 54 (1968) 8 p. 967

9 ）金尾, 青木, 荒木, 沼田：鉄と鋼，52（1966）4, p. 610

10) A. Kelly and R. B. Nicholson: Precipitation Hardening (Progress in Materials Science vol. 10), (1961), p. 216 